\section{Pedagogies of the Walking Dead}

Pedagogía de los muertos vivientes

\author{
Pedagogia dos mortos viventes
}

\section{Abstract}

This paper investigates the trope of the zombie and the recent upsurge in popular culture surrounding the figure of the zombie described as the "walking dead". We investigate this trope and figure as a means of analyzing the "pedagogy of the walking dead" with particular attention to the crisis of education in the era of neoliberal capitalism. In particular we examine the professionalization and responsibilization of teachers in the new regulative environment and ask whether there is any room left for the project of critical education.

\section{Key words}

Zombie culture, pedagogy of the walking dead, neoliberalism, teacher, professionalization, responsibilization

\section{Resumen}

El artículo analiza la metáfora de los zombis y el interés que en la cultura popular rodea la figura del zombi, o del "muerto viviente". Se analiza este tropo y figura como un medio para pensar la "pedagogía de los muertos vivientes", esto significa: la crisis de la educación en la era del capitalismo neoliberal. En particular, son examinadas la profesionalidad y la responsabilización de los docentes en el nuevo entorno regulatorio, con el propósito de indagar las posibilidades de un proyecto de educación crítica.

\section{Palabras clave}

Cultura zombi, pedagogía de los muertos vivientes, neoliberalismo, maestro, profesionalidad, responsabilización

\section{Resumo}

0 artigo analisa a metáfora dos zumbis e o interesse que na cultura popular aumenta em torno da figura do zumbi, ou do "morto vivo". Esta figura é analisada como um meio para pensar a "pedagogia dos mortos-vivos", isso significa: a crise da educação na era do capitalismo neoliberal. Em particular, examinou-se o profissionalismo e a responsabilização dos professores no novo ambiente regulatório, com o objetivo de investigar se é possível um projeto de crítica da educação.

\section{Palavras chave}

Cultura zumbi, pedagogia de mortos-vivos, neoliberalismo, professor, profissionalismo, responsabilização

Fecha de recepción: Septiembre 10 de 2015 Fecha de aprobación: Noviembre 23 de 2015

** Doctora en Filosofía Universidad de Auckland. Directora del Centro de Estudios Globales en Educación y Profesora de la Escuela Te Whiringa de Liderazgo y Política Educativa, Universidad de Waikato. 
Such behavior [this silencing] is terrorist. [...] not content with negative obedience, nor even with the most abject submission. When you do finally surrender to us, it must be of your own free will.

\section{Jean-Francois Lyotard, The postmodern condition}

The zombie-a creature who starts life as a normal human being, but through one process or another becomes "undead" and then wreaks havoc on the living -is used again and again in film, TV, print media of all kinds, video games, and even in popular music (the infamous "Thriller" video) to convey a basic loss of control and ability to reason with something that is basically indifferent, yet extremely motivated. The zombie, as it appears in modern Western culture, has become allegorical for an unthinking, unfeeling way of living and relating to others, and a bellwether of complete social collapse. At the same time, the zombie is unaware of the damage it is causing, because it is not, well, alive.

Course description at University of Baltimore, instructor Arnold T. Blumberg, http://www.ubalt. edu/news/news-releases. $\mathrm{cfm}$ ?id $=1295$

\section{Introduction: Zombie Theory}

$T$ The Walking Dead is a us TV series about a central character who awakens from a months-long coma to find an apocalyptic world overrun by flesh-eating zombies. The series is currently in its fifth season and had a strong critical reception and high ratings. ${ }^{1}$ Hollywood is overrun by zombies and blood-sucking vampires. ${ }^{2}$ One wonders why the us has become a zombie-obsessed vampiric culture. One explanation proffered is that apocalytic fictional narratives like the Walking Dead provide an opportunity to work through the trauma of the breakdown of ethical frameworks that were shattered as a result of world war II, or, perhaps, of the endless appetite for human violence demonstrated in a multipolar world with the rise of the non-state actor. ${ }^{3}$ Zombie-ism has

1 See the official website at http://www.amc.com/shows/ the-walking-dead

2 See the Twilight series at http://www.thetwilightsaga. com/. Some critics argue that this follows the Harry Potter saga, basically in part also a story about the Christian prohibition against sex before marriage i.e., pro-chastity and pro-life- https://spesunica.wordpress.com/2008/12/01/ is-twilight-anti-christian-yes/

3 See eg., http://www.livescience.com/27287-zombieapocalypse-world-war-ii.html and http://news.stanford.edu/ news/2013/february/why-zombie-fascination-022013.html also been further titillated by stories of gruesome murders involving cannibalism. ${ }^{4}$ Some argue these dramas are essentially about ourselves (what isn't?)the dark side that emphasizes what happens when humanity loses its ethical way. Nicholas Barber of the BBC explains:

It's now more than a decade since zombies began their relentless shuffle into the mainstream of popular culture [...] By the time Brad Pitt's World War $Z$ was released in June, it seemed it was several years late to the party. Surely there was nothing new to be said about the undead? That tardiness, along with reports of the film's troubled production, suggested that World War $Z$ would die a death at the box office. Instead, it went on to rake in $\$ 540 \mathrm{~m}$, making it one of 2013's ten biggest blockbusters...

And zombie fever hasn't been confined to cinemas. A comic-book series with the same grisly antagonists, The Walking Dead, was launched in 2003, and was adapted into a television series in $2010 \ldots$

To compare zombies to their rivals in the monstermovie pantheon, vampires and werewolves symbolise the thrill and the romance of having superhuman strength and no conscience-hence the Twilight and True Blood franchises. But there's nothing glamorous about being a zombie. Unlike vampires and werewolves, they're not frightening because of how powerful they are. They're frightening because of how dismal it would be to become one yourself. Another difference is that werewolves and vampires are content to share the planet with the rest of us.

He goes on to speculate:

It can't be a coincidence, then, that zombies are in vogue during a period when banks are failing, when climate change is playing havoc with weather patterns, and when both terrorist bombers and global corporations seem to be beyond the reach of any country's jurisdiction. It can't be a coincidence, either, that the fourth season of The Walking Dead got off to its hugely successful start just weeks after the United States federal government shut down. ${ }^{5}$

We use the term "Pedagogies of the Walking Dead" because the global situation has changed so dramatically since the Brazilian educational philosopher Paulo Freire wrote and published "Pedagogy of the Oppressed," in Portuguese in 1968, and in English in 1970. Freire's work based itself on phenomenological

4 See e.g., http://www.alternet.org/story/155783/what_does_ our_obsession_with_zombie_stories_tell_us_about_our_politics

5 See http://www.bbc.com/culture/story/20131025 -zombie-nation 
and existentialist Marxism, essentially a humanist blend of continental philosophy with an early Marx class orientation. It was imbued with sixties optimism, upbeat with human agency in changing the world for the better and for changing ourselves through the practice of freedom. It emphasized popular education and critical consciousness-the exact opposite of zombie-culture-and teaching for social justice. It spawned "critical pedagogy" based on educational praxis through critical thinking and critical literacy, of learning to read the word by reading the world. It promised equality and hope.

Today, after thirty-five years of neoliberalism-of the erosion of public education systems, attacks on teachers and public intellectuals, of privatisation strategies, and of new national testing and accountability regimes-the fire of pedagogical hope first lit up by Freire and carried forward by a generation of critical educators like Henry Giroux, Peter McLaren, and Joe Kinchloe seems less a raging bonfire than a scramble to keep alive the embers. ${ }^{6}$ The fire has not gone out but the public teaching profession is controlled and regulated by State agencies and often villified by those on the Right, mostly free-marketeers who in a self-serving way want to profit on the misery of the next generation of school children who are now forced to pay their way. They have been cannibalized by a system that feeds on its youth. Currently, us student loans have exceeded $\$ 1.2$ trillion dollars and become the second largest form of mortgage after housing.7 Schools have become marketplaces, students have become consumers, curricula have become commodities, as have all the digital software, books, and teaching equipment. Pedagogies are now technical recipes provided by big tech and publishing companies, supplemented by tech-support, Moocs and other broadcast, one-way media. Pedagogy of the Oppressed has become the Pedagogy of the Walking Dead as teachers are centrally regulated not only in the curriculum and syllabi by having to teach to targets and standards but also prescribed in terms of pedagogy and the style of teaching with little or no opportunity to raise a critical voice.

The journal Turbulence makes the case for zombie neoliberalism:

Neoliberalism is dead but it doesn't seem to realise it. Although the project no longer "makes sense", its logic keeps stumbling on, like a zombie in a

6 See the recent Paulo Freire: The Global Legacy (Peters \& Besley, 2015).

7 See https://studentloanreduction.com/student-loan-debt -reaches-record-1-2-trillion/ 1970s splatter movie: ugly, persistent and dangerous. If no new middle ground is able to cohere sufficiently to replace it, this situation could last a while [...] all the major crises-economic, climate, food, energy-will remain unresolved; stagnation and long-term drift will set in. Such is the "unlife" of a zombie, a body stripped of its goals, unable to adjust itself to the future, unable to make plans. A zombie can only act habitually, continuing to operate even as it decomposes. Isn't this where we find ourselves today, in the world of zombie-liberalism? The body of neoliberalism staggers on, but without direction or teleology. (http://turbulence.org.uk/ turbulence-5/life-in-limbo/)

Chris Harman (2010) in Zombie Capitalism: Global Crisis and the Relevance of Marx commented on how the "shadow" banking system based on speculation and unrealistic credit extension wreaked havoc on world markets and left human misery and devastation in its wake. Following the 2008 crisis many commentators talked about "zombie banks" that were "undead" in the sense that they were no longer functional or capable of achieving human goals. Harman argues that the whole system has become a zombie system.

Fred Bottling documents the 'Attack of Zombie Debt' that records the return of long term uncollected bad debts that are not written off but return after they are sold as low rates to specialized collection agencies. He writes:

Zombie debt is another manifestation of an apparently contagious association between finance and the walking dead. Like zombie economics, zombie banks, and zombie capitalism, the phrase seems to follow the logic of Ulrich Beck's "zombie categories" of modernity, in which old ideas, institutions, or practices persist despite having little currency, relevance, or credibility. The figure's return, however, also takes its generic bearings from a longer-standing gothic political-economic lexicon that goes at least as far back as Capital's images of industrial monstrosity and dead labor feeding on living, working bodies (Marx 506, p. 342). At the same time-and with the pop cultural nous of reflexive political media-its sense of a shifting financial mood responds to recent transformations in the political meanings of vampirism: the exciting figure of a voracious consumerist euphoria of unlimited desire (and credit) cedes to depressive stagnation and elegies for neoliberal fiscal strategy. 
Michael Sauga (2014) argues that capitalism has gone off the rails and does not service humanity's needs leading to the financial deformation of the system. ${ }^{8}$ He echoes the thoughts of many:

we are, in fact, living through a historic period tied to the image of the zombie because the system which dictates and dominates our globe, from the world-markets to the workplace to the propaganda machines, and I do not hesitate to name it-capitalism-, has in fact zombified right before our eyes, transforming into a monster that threatens to tear all of our lives apart, unless we can find some way to annihilate the sucker, or at the very least evade it until its virus extinguishes itself in an orgy of self-destruction. ${ }^{9}$

After 35 years of neoliberalism the question is whether there is a space to pursue critical pedagogy. In the neoliberal classroom has pedagogy become sanitized and lifeless-the pedagogy the walking dead? Are schools now only laboratories for producing digital labor in much the same way that industrial schools produced labor for factories? As the editors of this volume ask: Are we entering a post-pedagogical era? Does neoliberalism leave any room at all for social conscience, for the teacher's voice and, perhaps even more importantly, for the student's voice and for democratic action?

We use the term in a critical way to refer to a system that extracts more from teachers, a system that attempts to responsibilize teachers for student achievement and learning outcomes through new accountability regimes that tries to make teacher assessment dependent on standards and state mandated targets without recognizing structural inequalities. While it is the case that zombie culture might be an appropriate object of popular and critical inquiry and even used to aid critical pedagogy as some scholars claim, ${ }^{10}$ we use the term to describe a system that systematically robs teachers of professional autonomy through a variety of strategies: through curricula that specify in every finer detail expected outcomes, through assessment standards that encourages 'teaching to the test,' and through forms of teacher evaluation that increasingly

8 See The Zombie System: How Capitalism Has Gone Off the Rails at http://www.spiegel.de/international/business/ capitalism-in-crisis-amid-slow-growth-and-growinginequality-a-998598.html

9 See http://endofcapitalism.com/2012/11/27/ the-arrival-of-zombie-capitalism/

10 See eg http://www.slideshare.net/jessestommel/ zombie-pedagogies-embodied-learning-in-the-digital-age see pedagogy as a simple banking transaction. The system increase responsibilizes teachers while taking away their professional autonomy.

\section{Responsibilization and deprofessionalization}

There is a "new prudentialism" in education. Prudentialization results when education is addressed to the entrepreneurial self, or the "responsibilized" self who must make choices regarding his or her own welfare based on actuarial rationality. Such prudentialization seeks to "insure" the individual against risk in a context where the state has transferred risk to the individual. The role of social prudentialism in education has encouraged a shift in forms of social insurance through education from one welfare regime. The promotion of the entrepreneurial self represents a shift away from a rights-based welfare model of the citizen to a citizen-consumer model based on the rejuvenation of homo economicus, where individuals calculate the risks and invest in themselves at critical points in the life cycle.

The key elements of the risk-management program grow out of the shift from the Keynesian welfare state and compulsory social insurance to neoliberalism (or the culture of consumption) and a form of private insurance constructed through choice. Within this new regime (re/de)regulation represents an intensive juridification, a legal liberation and optimism based upon confidence in rules. On this model the well-governed society is committed to the coherence of a framework of rules, a codification, which allows the government to step back more and more from actual involvement in state activities, which now devolve to agencies, institutions, or regions. Government assumes the metaposition of rule-maker. In this political environment, the economic, constitutional, and legal or juridical forms of advanced liberalism overlap to construct the citizen-consumer. Increasingly, alongside the empowerment of consumers-simultaneously their individualization and their responsibilization is a belief in the efficacy of rules and a distrust of professionals. These knowledges and discourses grew up with the welfare state a fact evident in the role of the nineteenth-century census as an instrument of governmentality and came to have an independent existence over time. Understood as a risk-management regime, neoliberalism involves the dis- trust of expert knowledges, especially those traditionally associated with the welfare state such as the expertise of social workers and teachers. Under neoliberalism the trend has been toward creating a uniform structure of expert knowledges that is 
based on the calculating sciences of actuarialism and accountancy (thus explaining the label "the audit society"). "The social" is promoted as that which is capable of being governed, for example, the regulation of "the poor." "Work" and "unemployment" have in this way become fundamental modern categories of social regulation. In this sense, neoliberalism can be seen as an intensification of moral regulation resulting from the radical withdrawal of government and the responsibilization of individuals through economics. It emerges as an actuarial form of governance that promotes an actuarial rationality through encouraging a political regime of ethical selfconstitution as consumer-citizens. "Responsibilization" refers to modern forms of self-government that require individuals to make choices about lifestyles, their bodies, their education, and their health at critical points in the life cycle, such as giving birth, starting school, going to university, taking a first job, getting married, and retiring. "Choice" assumes a much wider role under neoliberalism: it is not simply "consumer sovereignty" but rather a moralization and responsibilization, a regulated transfer of choicemaking responsibility from the state to the individual in the social market.

We have passed from an ontology of the self as producer, which characterized the era of Left politics and the welfare state, to an ontology of self as consumer, which now characterizes politics of the Right, the neoliberal market economy, and the provision of public services. This shift can be characterized in terms of a symbolic economy of the self that involves processes of self-capitalization, self-presentation, self-branding, and self-virtualization as market processes having political, ethical, and aesthetic elements. We might follow Foucault's lead and focus on processes of political, ethical, and aesthetic selfconstitution through making choices that involve the purchase of goods and services and, in some cases, longer-term investment decisions.

A genealogy of the entrepreneurial self reveals that it is a relation that one establishes with oneself through forms of personal investment (including education, viewed as an investment) and insurance that become the central ethical and political components of a new individualized, customized, and privatized consumer welfare economy. In this novel form of governance, responsibilized individuals are called upon to apply certain managerial, economic, and actuarial techniques to themselves as citizen-consumer subjects calculating the risks and returns on investment in such areas as education, health, employment, and retirement. This process is both self-constituting and self-consuming. It is self-constituting in the
Foucaultian sense that the choices we make shape us as moral, economic, and political agents. It is selfconsuming in the sense that the entrepreneurial self creates and constructs him- or herself through acts of consumption.

Neoliberalism uses model of line management to inserts a hierarchical mode of authority by which the market and state pressures can be instituted. For teachers this carries with it the effect of deprofessionalization, involving a shift from collegial or forms of democratic governance in flat structures, to hierarchical models based on dictated management specifications of job performance in chains of command. The implementation of restructuring initiatives in response to market and state demands involves increasing specifications by management over workloads and course content. Such hierarchically imposed specifications erode traditional conceptions of professional autonomy over work in relation to both teaching and research. Neoliberalism systematically deconstructs the space in terms of which professional autonomy is exercised.

Traditional conceptions of professionalism involved an ascription of rights and powers over work in line with classical liberal notions of freedom of the individual. Market pressures increasingly encroach and redesign their traditional understandings of rights, as educational institutions must adapt to market trends (for example, just as individual departments and academics are being told of the necessity for acquiring external research grants, so they are also being told they must teach summer schools.)

The essence of contractual models involves a specification, which is fundamentally at odds with the notion of professionalism. Professionalism conveys the idea of a subject-directed power based upon the liberal conceptions of rights, freedom and autonomy. It conveys the idea of a power given to the subject, and of the subject's ability to make decisions in the workplace. No professional, whether doctor, lawyer or teacher, has traditionally wanted to have the terms of their practice and conduct dictated by anyone else but their peers, or determined by groups or structural levers that are outside of their control. As a particular patterning of power, then, professionalism is systematically at odds with neoliberalism, for neoliberals see the professions as self-interested groups who indulge in rent-seeking behaviour. In neoliberalism the patterning of power is established on contract, which in turn is premised upon a need for compliance, monitoring, and accountability organized in a management line and established through a purchase contract based upon measurable outputs. 
There are, roughly speaking, four different contemporary forms that accountability takes. We might call them accountability regimes. They are not mutually exclusive and may exist as hybrids. First, there is the state-mandated agency form that regulates activity or performance according to standards or criteria laid down at state or federal level. Typically, this form is often associated with devolution of management (though not necessarily governance) and the development of parallel privatization and/ or the quasi market in the delivery of public services. Second, there is professional accountability which tends to operate through the control of entry and codes of practice that are struck by professional associations, most often in occupations like law, accountancy, dentistry, doctoring. This professional self-regulation often does not include occupations like teaching and nursing, although it may include counseling. Third, there is consumer accountability, that is, accountability through the market, especially where consumer organizations have been strengthened in relation to the development of public services delivered through markets or market-like arrangements. Fourth, there is a form of democratic accountability that has its home in democratic theory and is premised on the demand for both internal and external accountability, that is, typically accountability of a politician to parliament or governing organization and accountability to his/her electorate. The second form or professional accountability may be seen, in reality, to be a form of the fourth or democratic form. Both proceed from Kantian-like assumptions about autonomy, self-regulation, duty and responsibility for one's actions whether this be in institutional (e.g., parliament, university) or individual terms.

There has been an observable tendency in Western liberal states to emphasize both agency and consumer forms at the expense of professional and democratic forms, especially where countries are involved in large-scale shifts from traditional Keynesian welfare state regimes to more market-oriented and consumer-driven systems. Indeed, it could be argued that there are natural affinities by way of shared concepts, understandings and operational procedures between these two couplets. One of the main criticisms to have emerged is that the agency/ consumer couplet instrumentalizes, individualizes, standardizes, marketizes and externalizes accountability relationships at the expense of democratic values such as participation, self-regulation, collegiality, and collective deliberation that are said to enhance and thicken the relationships involved.

\section{Responsibilizing Teachers: The International Agencies}

The UNESCO Institute for Statistics (2014) indicates that four million teachers will need to be recruited to achieve universal primary education by 2015 including some 1.6 million replacements by those retiring or leaving the occupation (see Figure 1.) As the Unesco paper demonstrates, there are massive and persistent teacher shortages which have the effect of denying the fundamental right of primary education to millions of children in the coming decades. ${ }^{11}$ The TALIS 2013 results: An international perspective on teaching and learning, ${ }^{12}$ the largest international survey of teachers, questioned teachers about conditions that lead to best learning environments dispelling some of the myths about the importance of class size and emphasizing the lack of team teaching, management feedback, and significant staffing shortages. Collectively teachers feel undervalued, unsupported and unrecognised. It is reported that in one third of countries less than $75 \%$ of teachers are trained. ${ }^{13}$ The Draft Declaration of the World Education Forum (WEF) 2015, Education 2030: Towards inclusive and equitable quality education and lifelong learning for all (WEF, 2015) articulates anew educational agenda based on the Sustainable Development Goal (SDG) 4 "Ensure inclusive and equitable quality education and promote life-long learning opportunities for all" emphasizing a framework for action that recognizes gender equality, fosters creativity, focuses on "functional literacy" for youth while noting "with serious concern that, today, more than onethird of the world's out-of-school population lives in conflict-affected areas, and crises, natural disasters and pandemics continue to disrupt education and development globally."14

While the international teacher advocacy groups like the International Taskforce of Teachers for Education for $\mathrm{All}^{15}$ supported equal rights and equal opportunity, the call to support public education is muted as is discussion of the privatization of public education. Even in the International Policy Dialogue Fora there is no mention of "neoliberalism" or its

\footnotetext{
11 See also the Unesco eAtlas of Teachers at http://tellmaps. com/uis/teachers/

12 See http://www.oecd.org/edu/school/talis-2013-results.htm

13 http://www.teachersforefa.unesco.org/v2/index.php/en/

14 See http://en.unesco.org/world-education-forum-2015/

15 See http://www.teachersforefa.unesco.org/v2/index.php/en/ about-us/our-mission/our-mission
} 
policy effect in eroding public education. How is it possible to talk, for instance, of the impact of financial crisis on teachers without mentioning neoliberalism or financial capitalism or financialization? Yes, this seems to be precisely what the report The 2010 education for all global monitoring report through a 'teacher lens' accomplishes. ${ }^{16}$

In this and subsequent fora there is a distinct reluctant to engage in any critical policy scholarship regarding neoliberalism and its erosion of public education, its effects on standards and assessment, on pedagogy and on the plight of teachers. By contrast, the emphasis is on global educational development, on inclusion of the 57.2 million children worldwide not in education, and on the "management" of teacher education. ${ }^{17}$ While the focus on equity, equality and on educational development in post-conflict zones is desirable, it is not clear how this target-orientation policy management approach can take place irrespective of the political context and the rise of neoliberalism with its emphasis on market solutions, on private schools, and on parallel policies of privatisation in the public sector. In an officials sponsored program with heads of Ministries and other government agencies it is perhaps no surprise that the recognition of public education is occluded, that there is no recognition of the background and struggles of teachers in the developed world to hold on to their role and status against the ravages of neoliberalism. Why would one even expect the word "resistance" to figure in such circumstances? One might ask whether there is indeed a practising teacher among these officials, or even an organisation that officially registers itself as an advocacy group on behalf of teachers?

It has been remarked that intergovernmental organization actually promotes neoliberal education policies as Rutkowski (2007, p. 229) argues: "[International] organizations encourage world change and promote particular ideologies through a set of complex actions and policy recommendations that exploit growing world interconnectedness." Sarah

16 http://www.teachersforefa.unesco.org/v2/phocadownload/ Publications/2010_synthesisgmr_english.pdf

17 The full list of policy fora is: 1. "Teachers, the Financial Crisis, and the EFA Challenge of Reaching the Marginalized" Addis-Ababa (Ethiopia, 22-23 February 2010); 2. "Providing Teachers for EFA: Quality Matters" Amman (Jordan, 6-7 July 2010); 3. "Ensuring Equity in Country Policies and Practices for Providing Quality Teachers toward Achieving the EFA Goals by 2015" Bali (Indonesia, 13-15 September 2011); 4. "Teachers challenges for EFA in India" (with global perspectives) New Delhi (India, 29-30 May 2012); 5. "Three Years of Global Partnership to Address the Teacher Challenge-Three Years from the 2015 EFA Benchmark: Achievements and Perspectives") Windhoek (Namibia, 28-29 November 2012).
Brouillette (2014) argues "Since the early 1980s Unesco has supported the neoliberal image of culture as a politically neutral resource that can be applied to capitalist development goals." ${ }^{18}$ Moosung Lee \& Tom Friedrich (2011) have shown that Unesco's social democratic liberalism that dominated lifelong learning policy during the period between the 1990s and the early 2000s has been increasingly supplanted by neoliberalism. Michelle Fawcett's (2009) research charts The market for ethics: Culture and the neoliberal turn at Unesco. Her research seeks

[...] to contextualize and theorize the institutionalization of public-private partnerships at the United Nations Educational, Scientific and Cultural Organization (Unesco). Once considered a radical organization by the U.S. government, Unesco now partners with corporations to launch projects that claim, among other things, to promote cultural diversity, bridge the digital divide or build intellectual property regimes. From peace to development as its institutional goal, from state to market as its mechanism of delivery and from the universal citizen to the local entrepreneur as its subject, Unesco is undergoing a dramatic shift in organizational focus, one better designed to serve corporate interests than foster public debate about the meanings and uses of culture.

\section{Neoliberalism and Teachers}

Lois Weiner, a Professor at New Jersey City University, and Mary Compton, past president of the UK National Union of Teachers, the largest teacher union in Europe, in "Neoliberalism, Teachers, and Teaching: Understanding the Assault" write (Compton \& Weiner, 2008):

Though the titles and acronyms of policies differ from one country to another, the basics of the assault are the same: undercut the publicly-supported, publicly-controlled system of education, teachers' professionalism, and teacher unions as organizations. The very nature of education is being contested: the Fourth World Congress of the international organization of teacher unions, Education International (EI), held in Brazil, explored the theme "Education: Public Service or Commodity?" Over the last couple of decades a new global consensus about reshaping economies and schools has emerged among the politicians and the powerful of the world. Whereas in the past governments-preferably democratically elected-have assumed the

18 See Unesco's Neoliberalism at http://www.buffalo. edu $/$ calendar $/$ calendar?action $=$ describe $\&$ which $=0638$ 6FF2-69c4-11E4-8BBE-B78c2C3EEDE4 
responsibility to ensure that all children are educated, schools and universities are now regarded as a potential market. In these educational markets, entrepreneurs set up schools and determine what is taught and how it is taught in order to make a profit. The assumption that schooling is a "public good" is under the most severe attack it has ever endured. Teacher trade unionists are grappling with the increasing privatization of education services, the introduction of business "quality control" measures into education, and the requirement that education produce the kind of minimally-trained and flexible workforce that corporations require to maximize their profits. Among scholars and global justice activists, these reforms being made to the economy and education are often called "neoliberal". ${ }^{19}$

We have examined some of these broader themes in a number of related publications. In Poststructuralism, Marxism, and neoliberalism: Between theory and politics Peters (2001) focused on two interrelated themes: the culture of Western Marxism and contemporary neoliberal capitalism in order to argue that poststructuralism is not a form of anti-Marxism. Poststructural philosophers view themselves in some kind of relationship to the legacy of Marx: either they have been Marxist or still view themselves as Marxist. In a post-Marxist era these philosophers have invented new ways of reading and writing Marx. We engage neoliberalism as a political project that is committed to the revitalization of homo economicus and neoclassical economics and provide a deconstruction of neoliberalism, considered as a world-historical political project aimed at a form of globalisation. ${ }^{20}$ The aim was to show that among poststructuralist philosophers all entertained a historical relationship to Marx and Marxism and some like Deleuze and Guattari regarded themselves as Marxist. This then was an argument for an understanding and analysis of neoliberalism by poststructuralist Marxist philosophers that emphasized human subjectivity even while problematising aspects of an essentialist humanism.

Neoliberalism is anti-teacher and anti-union. In many countries around the world neoliberal policies have tried to limit the power of the teacher collective, to criticize teacher education

19 http://newpol.org/content/neoliberalism-teachers -and-teaching-understanding-assault

20 See the review, Ulf Schulenberg,Amerikastudien / American Studies, Vol. 47, No. 3, Vladimir Nabokov at 100 (2002), pp. $430-432$ programs, to institute new forms of training that put graduates in front of children without appropriate experience of reflection.

In Neoliberalism and After? Education, Social Policy, and the Crisis of Western Capitalism Peters (2011) examined the era that began with the election of the Thatcher and Reagan governments, an era dominated by contemporary forms of neoliberalismbased market fundamentalism, globalization as world economic integration and the ideology of "free trade," and an attack on "big" government and social welfare. This book provided a historical and theoretical investigation of contemporary neoliberalism in relation to education policy and its rollback of the Keynesian welfare state. It argued that education is the basis of an open society and is a social welfare right in the emerging knowledge economy. Drawing on the theoretical lens of Michel Foucault's work on governmentality understood as a form of radical political economy, the book explored and critiqued neoliberalism as the ruling consensus. ${ }^{21}$

Education, Cognitive Capitalism, and Digital Labor (Peters \& Bulut, 2011) focused on the attempt to understand neoliberalism in the epoch of digital reason, including fundamental changes to the nature of capitalism and new forms of educational capitalism centered around the question of digital labor. ${ }^{22}$

One of the pressing questions surrounds the nexus among the forces of neoliberalism, globalisation and finance capitalism especially in terms of new forms of educational capitalism that erodes the public sector and turns the sector over to for-profit capitalists either in the form of charter schools or whole system providers.

Digital labor now is the next struggle with large global information utilities like Google, Facebook and Amazon.com that control the digital sphere in terms of a scale that dwarfs industrial capitalism and threatens to turn the school into a provider of digital skills. To return to the original metaphor of the zombie and the figure of zombie culture, we must deal with what Danny Weil calls "zombie functionalism" that represents the return of instrumentalism

21 See the following reviews: Darko Štrajn (2012). International Review of Education, 58, (4), 585-587; Scott Ellison, (2013). Transformational crisis? Thinking within and beyond the limits of neoliberal education policy, International Education, 42 (2). Retrieved from: http://trace.tennessee.edu/ internationaleducation/vol42/iss2/7

22 See "Control and becoming in the neoliberal teaching machine," Amit S. Rai, review of Michael Peters and Ergin Bulut (2011) Cognitive capitalism, education, and digital labor. http://www.ephemerajournal.org/contribution/control-and -becoming-neoliberal-teaching-machine 
in education. ${ }^{23}$ This kind of functionalism affects methods of instruction, destroys professional autonomy, prescribes the curriculum even more closely and reduces students to

"mere depositories of pre-masticated thinking." This is an environment where "Testing is an authoritarian tool that regiments both students and teachers while at the same time serving as a rubric for investors who see the scores much like credit ratings." Critical thinking is discouraged and learning lapses into a non-questioning acceptance of packaged 'ideas.'

With the privatisation of schooling, the growth of charter schools, and the attack upon teachers and state systems, inequalities have begun to balloon out of control. Diane Reay (2006), quoting Ulrich Beck (2004) on social class as a "zombie category" (embodying nineteenth century experience), charts the increase in relative poverty in British society and argues for the reinvigoration of social class analysis in sociology of education. Diane Kern (2013) after an exhaustive review concludes "High-stakes testing as a determinant of the awarding of a high school diploma is a zombie idea in education" (p. 5).

Zombie culture in education and society at large reveals education as a living death. This zombiefication takes places across all sector infecting education with a deadly virus that highlights moribund contents and a contagion of market ideas that casts heaps of educational corpses in its wake (see also Whelan et al, 2013).

Henry Giroux (2011) in Zombie Politics and Culture in the Age of Casino Capitalism, at the dust jacket says

[...] uses the metaphor not only to suggest the symbolic face of power: beginning and ending with an analysis of authoritarianism, it attempts to mark and chart the visible registers of a kind of zombie politics, including the emergence of right-wing teaching machines, a growing politics of disposability, the emergence of a culture of cruelty, and the ongoing war being waged on young people, especially on youth of color.

William Astore (2013) says it plainly enough: "When education becomes a commodity and students become consumers, the result is zombie education."24

\section{References}

Beck, U. (2004). Ulrich Beck - Johannes Willms: Conversations with Ulrich Beck. (M. Pollak, Trans.). London: Polity Press-Blackwell Publishing.

Compton, M. \& Weiner, L. (2008). Neoliberalism, Teachers, and Teaching: Understanding the Assault. New Politics, XII(1).

Kern, D. (2013). Zombie ideas in education: High-stakes testing and graduation policies. New England Reading Association Journal, 49(1), 96.

OECD (2013). TALIS 2013 results: An international perspective on teaching and learning. OECD Publishing. Available at http://dx.doi.org/DOI:10.1787/9789264196261-en

Peters, M.A. (2001). Poststructuralism, marxism, and neoliberalism: Between Theory and Politics. Boulder, Rowman \& Littlefield.

Peters, M. A. (2011). Neoliberalism and after? Education, social policy, and the crisis of western capitalism. New York, NY: Peter Lang.

Peters, M.A. \& Bulut, E. (2001). Education, cognitive capitalism, and digital labor. New York. Peter Lang.

Reay, D. (2006, September ). The zombie stalking English schools: Social class and educational inequality. British Journal of Educational Studies, 54 (3), 288-307.

Rutkowski, D. (2007). Converging us softly: How intergovernmental organizations promote neoliberal educational policy, Critical Studies in Education, 48 (2), 229-247. Available at http://dx.doi. org/10.1080/17508480701494259

Unesco Institute for Statistics (2014). Wanted: Trained teachers to ensure every child's right to primary education. Policy paper 15, Fact sheet 30, at http://www.uis. unesco.org/Education/Documents/fs30-teachers-en. pdf

WEF (2015). Education 2030: Towards Inclusive and Equitable Quality Education and Lifelong Learning for All at http://www.uis.unesco.org/Education/Documents/ education_2030_incheon_declaration_en.pdf

Whelan, C.; Walker, R. \& Moore, C. (2013). Zombies in the academy: Living death in higher education. Chicago: University of Chicago Press.

23 See http://philosophersforchange.org/2012/08/07/zombiefunctionalism-and-the-return-of-neo-instrumentality-ineducation/

24 See http://www.truth-out.org/opinion/ item/17103-the-perils-of-zombie-education 


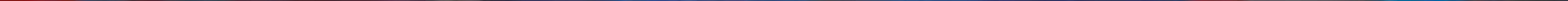

